University of Nebraska - Lincoln

DigitalCommons@University of Nebraska - Lincoln

2011

\title{
A history of NASA remote sensing contributions to archaeology
}

Marco J. Giardino

Stennis Space Center

Follow this and additional works at: https://digitalcommons.unl.edu/nasapub

Part of the Physical Sciences and Mathematics Commons

Giardino, Marco J., "A history of NASA remote sensing contributions to archaeology" (2011). NASA Publications. 56.

https://digitalcommons.unl.edu/nasapub/56

This Article is brought to you for free and open access by the National Aeronautics and Space Administration at DigitalCommons@University of Nebraska - Lincoln. It has been accepted for inclusion in NASA Publications by an authorized administrator of DigitalCommons@University of Nebraska - Lincoln. 


\title{
A history of NASA remote sensing contributions to archaeology
}

\author{
Marco J. Giardino* \\ NASA, Stennis Space Center, Building 3204, Room 200A, Stennis Space Center, MS 39529, United States
}

\section{A R T T I C L E I N F O}

\section{Article history:}

Received 28 December 2009

Received in revised form

10 September 2010

Accepted 15 September 2010

\section{Keywords:}

NASA

Stennis space center

Archaeology

Remote sensing

History

Hyperspectral

\begin{abstract}
A B S T R A $T$
During its long history of developing and deploying remote sensing instruments, NASA has provided scientific data that have benefitted a variety of scientific applications among them archaeology. Multispectral and hyperspectral instruments mounted on orbiting and sub-orbital platforms have provided new and important information for the discovery, delineation and analysis of archaeological sites worldwide. Since the early 1970s, several of the ten NASA centers have collaborated with archaeologists to refine and validate the use of active and passive remote sensing for archaeological use. The Stennis Space Center (SSC), located in Mississippi USA has been the NASA leader in archaeological research. Together with colleagues from Goddard Space Flight Center (GSFC), Marshall Space Flight Center (MSFC), and the Jet Propulsion Laboratory (JPL), SSC scientists have provided the archaeological community with useful images and sophisticated processing that have pushed the technological frontiers of archaeological research and applications. Successful projects include identifying prehistoric roads in Chaco canyon, identifying sites from the Lewis and Clark Corps of Discovery exploration, and assessing prehistoric settlement patterns in southeast Louisiana. The Scientific Data Purchase (SDP) stimulated commercial companies to collect archaeological data. At present, NASA formally solicits "space archaeology" proposals through its Earth Science Directorate and continues to assist archaeologists and cultural resource managers in doing their work more efficiently and effectively. This paper focuses on passive remote sensing and does not consider the significant contributions made by NASA active sensors. Hyperspectral data offers new opportunities for future archaeological discoveries.
\end{abstract}

(c) 2010 Published by Elsevier Ltd.

\section{Introduction}

On June 3,1965, a Titan II rocket blasted off from Launch Complex 19 located at the Kennedy Space Center in Florida. Riding on top of the rocket was the Gemini 4 capsule carrying Commander James McDivitt and Pilot Edward White, II. White would conduct the first USA "spacewalk" or EVA (Extra Vehicular Activity) operation, lasting $36 \mathrm{~min}$. Less momentous for space travel, but more far-reaching for Earth scientists were the photographs of the Earth taken by the astronauts. Gemini 4 became the first formal photographic experiment from space. The astronauts collected 207 color photographs of the Earth for geologic, geographic, and oceanographic studies using a hand-held 70-mm Hasselblad 500-C camera with a Zeiss planar $80-\mathrm{mm} \mathrm{f} / 2.8$ lens and haze filter to reduce the intensity of atmospheric scattering. Each image had nominal scales 1:2,400,000 and included about $140 \mathrm{~km}$ on a side. Gemini's earth images were part of the Synoptic Terrain Photography and the Synoptic Weather Photography experiments and were acquired between March 23, 1965, and November 15, 1966, (Gemini Missions III through XII).

\footnotetext{
* Tel.: +1 2286882739 (office); fax: +1228688 1153 (office).

E-mail address: marco.j.giardino@nasa.gov.
}

Follow-on NASA manned missions continued and improved the imaging of our planet. In 1968, the Apollo 9 mission produced the first multi-spectral photography from space. Four Hasselblad cameras mounted in an instrument rack were engineered to trigger simultaneously over the same target. Each of the four cameras collected reflected light in specific wavelengths, including for the first time, the infrared portion of the electromagnetic spectrum (EMS).

Scientists, including archaeologists, did not miss the opportunity to investigate the potential of NASA's Earth images, particularly those collected in the infrared. Over the next 50 years, archaeologists used a variety of ever-more sophisticated techniques to identify, delineate and analyze archaeological sites and their surroundings. Throughout the age of archaeological exploration through remote sensing, NASA has contributed both directly and indirectly to furthering the use of satellite and sub-orbital platforms as tools for archaeological research.

\section{First archaeological applications of NASA remote sensing}

Among the first archaeological applications of NASA imagery were the identification of ancient Hohokom canal systems by Yehuda Kedar (UC Santa Barbara, Geography Department). Using 
black and white as well as infrared photography from the S065 multiband experiment flown on Apollo 11, Kedar was able to identify the linear features built by prehistoric people in the Phoenix Arizona area (Schaber and Gumerman, 1969).

Two archaeological expeditions in Europe experimented with similar technology around the same time as Kedar's work in Arizona. The University of Minnesota expedition to Messenia Greece in 1969 used a balloon to collect data using black and white color and infrared films with a Hasselblad El 500 developed for NASA's Apollo 11 Moon landing mission. The same camera and techniques were deployed by scientists from U.S. Army, the University of Missouri and the American Academy of Rome over the ancient harbor of Cosa, in Tuscany. The infrared portion of the spectrum especially provided new and exciting information from both these sites (MASCA Newsletter, 1969: 2-3). Writing for the journal Science in 1971, George Gumerman and Thomas Lyons declared: "the color infrared image, correctly interpreted, can guide the archaeologist to previously undetected potential targets...The potential usefulness of infrared imagery to archaeology consists of the fact that, like color infrared film, buried or obscure cultural features may absorb and radiate solar energy in amounts that differ from that of the surrounding soil matrix, thereby revealing the features on the imagery." (Gumerman and Lyons, 1971:130)

In the United States, NASA was beginning to appreciate the "serendipitous" benefit of the developing space technology for studying ancient cultures. In 1970 a young NASA summer intern, originally hired by NASA HQ as a clerk-typist, was encouraged by Dr. Eugene Emme, NASA's first historian, to investigate the potential applications of NASA remote sensing instruments for archaeological research. Mary Marguerite Scalera contacted Thomas R. Lyons, who at the time was Assistant Director of the Technology Applications Center at the University of New Mexico, and Mr. Gary North, a Remote Sensing Specialist, Geographic Applications Program, U.S. Geological Survey for advice on her project.

Her report summarized about six archaeological projects that were utilizing NASA remote sensing instruments at that time. Scalera concluded her internal report with a highly optimistic forecast for the future of NASA "Space Age" technology to archaeology, a declaration that would prove prophetic (Scalera, 1970).

Three years after Scalera's report, NASA initiated the manned Skylab missions (named Skylab 2, 3 and 4 respectively) which added over 35,000 images of the Earth to the growing archives of Earth photographs. Flying on Skylab was the Earth Resources Experiment Package (EREP) which included an array consisting of six $70 \mathrm{~mm}$ cameras each equipped with different film and filter combinations to record images in narrow band black-and-white $(500-600 \mathrm{~nm}$ and $600-700 \mathrm{~nm})$, broad-band color $(400-700 \mathrm{~nm})$ and color and black-and-white near infrared. The nominal spatial resolution of the $190 \mathrm{~A}$ camera system was $30 \mathrm{~m}$ for each square image which measured $163 \mathrm{~km}$ on the side. While the 190A system had been successful during the Apollo 9 mission, the other instruments located on Skylab were experimental and radiometric rather than photographic. Two of these, a spectrometer (S191) and a 10-band multi-spectral scanner (S192), operated in the infrared. The spectrometer recorded the wavelength and intensity of infrared radiation from selected small areas $(0.45-\mathrm{km}$ diameter) on the ground; the multi-spectral scanner simultaneously measured the intensity of infrared in 10 wavelength ranges, scanning a swath $74 \mathrm{~km}$ wide centered on the spacecraft's ground track (Compton and Benson, 1983; Belew and Stuhlinger, 1973). Skylab imagery and photographs, together with the vast majority of NASA imagery, are available from the United States Geological Survey (USGS) EROS data center. Skylab imagery has not been widely used for archaeological research. Still, Skylab images were useful in identifying linear features, such as prehistoric irrigation canals in the southwestern United States (Ebert and Lyons, 1980).

Just one year prior to Skylab, on July 23, 1972, NASA launched the first in a series of Earth Resources Technology Satellites (ERTS 1) which in many ways revolutionized how archaeologists conduct their work. The ERTS Program and the satellites were later renamed Landsat to better represent the satellite program's prime emphasis on remote sensing of land resources. Seven Landsat satellites have been launched since 1972, with six of them achieving orbit and providing images from around the world. The USGS EROS Data Center (EDC) retained primary responsibility as the Government archive of Landsat data.

The sensors mounted on the various Landsat platforms (MSS or Multispectral Scanner; the TM or Thematic Mapper; the ETM or Enhanced Thematic Mapper and the ETM + flown on Landsat 7) are well known and well documented (Short, 1982). The MSS systems were the first global monitoring systems capable of producing multi-spectral data in a digital format. Since the early 1970s, the Landsat series of satellites has been widely used in archaeology as archaeologists gained experience and confidence in the use of multi-spectral data for a variety of archaeological applications (Miller, 1974; McKee and Sever, 1994:139-140).

The National Park Service (NPS) carried out some of the earliest and most extensive applications of NASA's satellite imagery to archaeology. Under the leadership of Thomas Lyons and James Ebert, NPS archaeologists researched the feasibility of using satellite imagery to identify village sites in Alaska (Cook and Stringer, 1972) and prehistoric sites and roadways in Chaco Canyon, New Mexico (Lyons and Hitchcock, 1977). In 1977, Lyons and Avery published an influential guide to using remote sensing for archaeological research (Lyons and Avery, 1977), followed by two additional and important publications on remote sensing and cultural resources (Lyons and Ebert, 1978; Lyons and Mathien, 1980). The amount of work on applying remote sensing to archaeology was already significant by the late 1970 s so that a preliminary bibliography was feasible and necessary (Kruchman, 1976).

In the 1980s, archaeology saw a notable increase in the use of NASA remote sensing imagery and some applications went beyond site identification toward the exploration of increasingly more complex issues, such as testing predictive models of site distribution. One such successful application of remote sensing in eastern US archaeology was conducted during the early 1980s in Delaware (Wells et al., 1981; Custer et al., 1986). Here Custer and his colleagues subdivided a large portion of central Delaware into broad land cover and hydrological classes using Landsat MSS imagery. They found that these modern land use classes were correlated with edaphic factors known to influence prehistoric settlement choices. Given this base map, Custer and his colleagues were able to statistically characterize the distribution of known sites in relation to these major land and water classes. The settlement model derived from this exercise proved to be over $90 \%$ accurate in predicting site locations in unsurveyed areas. Numerous projects using satellite imagery were undertaken in archaeology throughout the world, each forging new methods, identifying challenges and providing NASA with increased rationale for formalizing its role in archaeology (see for example, Johnson et al., 1988; Parcak, 2009). Prominent among the pioneers of satellite remote sensing and archaeology in the United States are Scott Madry from University of North Carolina, Chapel Hill, Jay Johnson, University of Mississippi, Fred Limp, University of Arkansas, James Wiseman, Boston University and Tom Sever, NASA (Limp, 1989; Wiseman, 1984; Madry, 1983; Johnson, 2006). 


\section{NSTL conference}

In 1983, Dr. Thomas Sever of the NASA Stennis Space Center (then known as the National Space Testing Laboratory or NSTL) produced an internal NASA document whose objective was to assess the feasibility of "remote sensing techniques for delineating and inventorying archaeological sites and features in order to expedite survey and excavation" (Sever, 1983). Sever proposed imaging Chaco Canyon using two airborne multi-spectral scanners: the Thematic Mapper Simulator (TMS) and the Thermal Infrared Multispectral Scanner (TIMS) which are discussed in Section 1.4.1.

NASA responded positively to Sever's proposal and in March of 1984, Sever joined James Wiseman from Boston University in sponsoring a conference on remote sensing and archaeology (Sever and Wiseman, 1985). The objective of the conference was "to bring together a group of archaeologists representing a broad spectrum of archaeological concerns to learn more about the recent advances in NASA's remote sensing technology and to discuss possible future applications of that technology in archaeology." (Sever and Wiseman, 1985:1). The conference was jointly funded by NASA, the National Science Foundation, and the National Geographic Society and was attended by 22 prominent professional archaeologists, including Patty Jo Watson (Washington University), John Yellen (Smithsonian), Glyn Isaac (Harvard University), Richard MacNeish (Boston University) and Robert McAdams, then Provost at the University of Chicago.

The participants were convinced that NASA remote sensing technologies would benefit archaeological research and that NASA and the archaeological community should become involved in joint research projects. They sought consensus on which areas of archaeological research, and what kinds of archaeological problems, should be the focus of the first remote sensing applications and generally agreed that these included: site location and point resource, the range of paleo-environmental resources, ecology, mapping, hypothesis formulation (predictive modeling) and testing, cultural resource management, and general ethnological investigations. The group concluded that the most immediate applications of remote sensing technology and image processing should be in the analysis of the environments of human societies and their interrelationships, thereby generating and testing models both of human behavior and environmental change. The conference participants especially encouraged projects that brought these applications to bear on endangered resources worldwide. Finally, the conferees agreed that ground truth "should include not only direct observation aimed at confirming or rejecting a proposed spectral identification but also some amount of ground search in areas where the computer images do not indicate by spectral signature the kind of site or natural resource that is an object of the research" (Sever and Wiseman, 1985:71-2).

\section{Sub-orbital remote sensing}

Starting in the early 1980s, and continuing to the present, Landsat imagery has been the preferred platform for archaeological research in the United States. SPOT data offered better spatial resolution and was utilized in a few archaeological projects in the United States. But mostly, archaeologists interested in satellite data gravitated toward Landsat, particularly bands 4-3-2 (IR, red, green) (Parcak, 2009; McKee and Sever, 1994).

Initially, the use of sub-orbital or aerial platforms to collect multi-spectral and hyperspectral remote sensing data was not broadly considered or available to the archaeological community even though aerial photography was widely used as an archaeological tool. Archaeologists wanted data with higher spatial resolutions, and were intrigued also by the potential offered by finer spectral resolution, including the thermal wavelengths. The advantage of collecting data using airborne platforms included the ability to vary the ground sampling distance (GSD) by varying platform altitude and the ability to fly on demand. It was in this arena, that NASA's Stennis Space Center (SSC) pioneered several efforts that furthered archaeological applications (Parrington, 1983).

\subsection{Stennis space center sub-orbital program}

In the early 1980s, two SSC airborne sensors became the workhorses of archaeological remote sensing: the Thematic Mapper Simulator (TMS) and the Thermal Infrared Multispectral Scanner (TIMS). TMS simulated the Landsat Thematic Mapping (TM) instrument, with slightly higher spatial resolution. The sensor collected 8-bit data in 12 bands from visible to thermal. In order to produce imagery with $30 \mathrm{~m}$ spatial resolution, the TMS was flown at $12,000 \mathrm{~m}$ above mean terrain elevation. The TMS scanner system was developed by Daedalus (known as the AADS-1268 scanner) and flew on ER-2 aircraft. Color IR photography was acquired simultaneously with 60 percent forward overlap for stereoscopic viewing.

The instrument was used to detect archaeological features in Western Kentucky (Mid-America Remote Sensing Center, 1983); Poverty Point (Gibson, 1984, 1987, 1989; Sever and Wiseman, 1985); and protohistoric sites in northern Mississippi (Johnson et al., 1988) and Anasazi roads in Chaco Canyon (Sever, 1983, 1990; Sever and Wagner, 1991). To search for prehistoric roads in Chaco Canyon, the TMS was also flown at an altitude of $4267 \mathrm{~m}$ resulting in $10-\mathrm{m}$ spatial resolution. Processing of the TMS data over Chaco Canyon using Earth Resources Laboratory Application Software (ELAS) software (also developed at Stennis) revealed that image enhancement techniques were successful in detecting the existence of prehistoric roadways particularly in the thermal band (10.43-12.33 $\mu \mathrm{m})$ (Sever, 1983:12).

The other important airborne sensor used in archaeology during the 1980s was the Thermal Infrared Multispectral Scanner (TIMS). This instrument was a six-channel multi-spectral spectrometer which measures radiation only in the thermal infrared (9400-12200 nm) at intervals between bands varying from $400 \mathrm{~nm}$ between 8.2 and 9.4 microns and in 800 and $1000 \mathrm{~nm}$ between 9.4 and 12.2 microns (Kahle and Abbott, 1986; Bennett et al., 1986). TIMS measured thermal radiation in degrees centigrade with accuracies better than a tenth of a degree, which translated operationally to accuracies of a half of a degree $C$ after atmospheric correction. The TIMS was especially important in "thermal" archaeology because it was multi-spectral in the thermal recording emitted energy in multiple bands.

Developed by NASA's Jet Propulsion Laboratory (JPL) and flown on the NSTL Learjet, the TIMS was funded by the NASA geology program in 1981 and built by Deadalus Enterprises, Inc. of Ann Arbor, Michigan. Like all airborne sensors, the TIMS' ground sampling distance was controlled by the aircraft's altitude so that flying at $2000 \mathrm{~m}$ the nominal pixel resolution was $5 \mathrm{~m}$.

During the early 1980s, NASA flew the TIMS in two archaeological projects, one over Chaco Canyon looking for prehistoric roads, the other at Poverty Point Site in Louisiana. This latter site is an impressive 400 -acre site dating to 1500 B.C.E. and consisting of a complex assortment of mounds, concentric ridges and "avenues". The TIMS data, particularly Band 3 (9.0-9.4 microns), when processed with high-pass filters, dramatically highlighted the aisles to the northwest and southwest (Gibson, 1984; Rickman and Kalcic, 1982). In addition TIMS data demonstrated that soil conditions at Poverty Point that are characterized by phosphate concentration possibly indicative of human habitation, have sufficiently strong signatures to be regularly detected. 
In 1987, NSTL designed and built the Calibrated Airborne Multispectral Scanner (CAMS), a nine channel broad-band multispectral instrument measuring energy between 0.45 and 12.5 microns. Two years later NSTL developed the Airborne Terrestrial Applications Sensor or ATLAS which combined the spectral characteristics of the TIMS and CAMS in a single instrument. ATLAS, like its predecessors, was an airborne multi-spectral instrument that gathered reflected and emitted energy in 14 bands from 0.45 to $12.2 \mathrm{~mm}$. The sensor (IFOV 2.0 mrads) collected data with ground resolutions ranging from $2.5 \mathrm{~m}$ to $25 \mathrm{~m}$ depending on the altitude of the NASA Stennis Learjet 23 which served as its platform. Two onboard blackbodies served as calibration instruments for the thermal bands. Color infrared photography was shot concurrently using a Zeiss RMK A 15/23 Camera loaded with Kodak 1443 Aerochrome III CIR. The ATLAS collected 8-bit data on 5 GB analog tapes, requiring numerous landings for data downloads. The data, once collected, needed to be processed through an analog-digital converter.

The data collected from all four airborne sensors (TMS, TIMS, CAMS and ATLAS) were reformatted into the ELAS format. The ELAS software package consisted of a Fortran-based operating system which provided advanced processing capability for remotely sensed digital data (Junkin et al., 1981). This image processing software was used extensively to develop archaeological information products until the advent of commercial software packages like ERDAS Imagine and ENVI in the early 1990s. With the development of the ATLAS, NSTL (now renamed the Stennis Space Center) improved and expanded on its pioneering work in archaeological remote sensing.

In a 1993 review of remote sensing in southeastern US archaeology, Fred Limp noted that one limitation at the time was that the imagery available was poorly suited for detecting small targets. The Stennis Space Center increased its involvement in airborne imaging to address, among other issues, the need for improved spatial resolution for archaeology. A new program managed at Stennis in the late 90s further improved the availability of high spatial resolution data.

\section{NASA scientific data purchase (SDP) program}

NASA's Scientific Data Purchase (SDP) Program implemented by the Stennis Space Center Earth Science Application Directorate in fiscal years 1998-2002 results in several advances in the use of remote sensing in archaeology. SDP was one in a series of congressionally funded demonstration projects for evaluating the utility of commercial remote sensing data for scientific purposes (NASA/SSC 2003). A number of commercial vendors were selected to provide scientific data for a variety of research and application projects. Most relevant to archaeological applications were: Positive Systems of Whitefish, Montana which collected airborne high spatial resolution multi-spectral data with its ADAR 5500 camera (Airborne Data Acquisition and Registration); Earth Watch, Inc. (formerly Digital Globe) of Longmont, Colorado which partnered with Intermap Technology to provide radar and elevation data from the airborne Interferometric Synthetic Aperture RADAR (IFSAR) system STAR 3i X which collected radar imagery at $2.5 \mathrm{~m}$; and Space Imaging, LLC (now GeoEye) of Thornton, Colorado providing $1 \mathrm{~m}$ pan and 4-m multi-spectral 11-bit data in the visible and the near-IR wavelengths data from its orbiting IKONOS satellite.

NASA partnered with several institutions to deliver high quality commercial data products for archaeological research. Through the SDP, Stennis provided a variety of data products for Boston University's projects in Aksum, Ethiopia and Holmul, Guatemala; for NASA's Marshall Space Flight Center archaeology work in Central America, and for UCLA, who in partnership with the Centro
Interdipartimentale di Servizi di Archeologia Istituto Universitario Orientale, Naples, Italy, conducted archaeological research of early Greek and Roman settlements in the Italian peninsula, and finally for Rutgers University in support of paleoanthropological research in Koobi Fora, Kenya (Dibble, 2006). SSC and EPA's Gulf of Mexico Program collaborated with state agencies in Veracruz to further the analysis of several important Olmec sites including San Lorenzo, Laguna de los Cerros, Tres Zapotes, and El Zapotal through the use of commercial data.

One project supported through the SDP and later continued through funding by the Stennis Space Center coincided with the 200th anniversary of the Lewis and Clark Corps of Discovery Expedition to explore the Western United States.

\subsection{Lewis and Clark bicentennial project}

The NASA Lewis and Clark project coincided with the Corps of Discovery Expedition bicentennial (2003-2006) celebration. The objective of the project was to demonstrate the potential of integrated remote sensing and GIS for site-specific studies of Lewis and Clark encampments. NASA SSC partnered with Montana University and the Columbia Gorge Discovery Center to map and identify Lewis and Clark sites using both IKONOS and ATLAS airborne data. The project also developed map products that could reconstruct 360 views of the landscape traversed by Corps of Discovery Expedition in the early 19th century, and compared their journal entries and historical documents to modern landscapes using remote sensing imagery.

Ken Karsmizki of the Columbia Gorge Discovery Center had been searching for Lewis and Clark sites for several years. He provided NASA with copies of the original Clark maps and a prioritized list of archaeological research objectives. Remote sensing scientists at Stennis Space Center enhanced satellite imagery (initially LANDSAT and AVHRR) with elevation models to project the historic Lewis and Clark maps onto the current topography. William Clark who produced the vast majority of the maps collected during the Corps of Discovery Expedition (1804-1806) often denoted the location of bluffs on his charts which unlike the river courses remained relatively stable over the centuries. The elevation models developed by SSC included the location of the riverine bluffs along the route and so served to refine the predicted locations for several important sites such as Fort Clatsop (Karsmizki et al., 2003a), the location of the Iron Boat burial site (Karsmizki et al., 2003b), Rock Fort Camp Site, and the Dalles, in Oregon (Karsmizki et al., 2004).

The co-registration of modern digital images with Clark's historic maps completed during the Lewis and Clark project provided a very valuable product for focusing the ground search for specific sites. This approach was implemented by NASA in other projects, including that conducted at Gainesville, Mississippi (Section 1.6). Another product developed during the Lewis and Clark project was the virtual and accurate rendering of several historic Corps of Discovery sites, especially Fort Clatsop. These virtual products enhanced scientific research and served to educate and inform the general public about the project and its results.

By the conclusion of the project, a total of 30 different NASA space borne remote sensing datasets were effectively processed. These included MODIS (Moderate Resolution Imaging Spectroradiometer) 8 day average reflectance; Shuttle Radar Topography Mission (SRTM) hill shaded digital elevation model (DEM) data at $750 \mathrm{~m}$ spatial resolution; orthorectified mosaics of Landsat TM and ETM data; eleven scenes of ASTER imagery plus four datasets from the International Space Station and nine from the Space Shuttle platforms. In addition, pan-sharpened byproducts of 19 commercial high-resolution satellite image datasets (seven from IKONOS and 
twelve from QuickBird) were processed and ingested into the ArcSDE. Finally, three scenes of geo-referenced ATLAS multi-spectral bands 12,6,2 (TIR, NIR, Green) at spatial resolutions ranging from 2.5 to $4 \mathrm{~m}$ were provided to the archaeologists for Fort Clatsop in Oregon, The Dalles in Oregon, and over the Upper Portage Camp in Montana. When co-registered to the IKONOS data, the ATLAS datasets provided a method to view spectral response in the thermal wavelengths, not available from IKONOS and QuickBird.

\section{Gainesville, Mississippi and the Stennis Space Center Buffer Zone archaeology}

Lessons learned during the Lewis and Clark Project were applied for the study and preservation of several historic localities situated within the Stennis Space Center. The Gainesville site is one of five historic towns that were evacuated when the area became part of the Stennis Space Center Buffer Zone and Fee area in 1962 with the advent of the Saturn rocket program. Gainesville had been the county seat of Hancock County, Mississippi, during the mid-19th century and even though no buildings were left standing, many subsurface features were still in situ.

Armed with high-spatial resolution multi-spectral data from orbiting platforms, NASA researchers pursued the co-registration of historic plats and maps to the digital data (IKONOS, QuickBird and airborne ATLAS) to identify historic boundaries and structures. Digital elevation models were developed with the use of LiDAR and RADAR imagery which when utilized in combination with $X$ and $Y$ coordinates derived from high spatial resolution imagery, produced accurate 3-D renderings of sites and the surrounding environment. This approach provided more precise locations of these historic sites and features, produced very accurate site maps, and allowed development and testing of predictive site location models. NASA is developing the Gainesville site as an archaeological validation and verification site for the application of a variety of remote sensing data collection and interpretation methods including ground penetrating radar, magnetometry and resistivity, and hyperspectral data from an airborne platform.

\section{Coast 2050 cultural resources survey}

One final notable archaeological project undertaken by archaeologists at the Stennis Space Center was the remote sensing survey of 50,000 acres of Coastal Louisiana for the detection of archaeological sites. The survey, conducted in collaboration with the U.S. Army, Corps of Engineers in New Orleans was a part of the "Coast 2050" program which was funded to understand and mitigate the massive losses of wetlands occurring in Southeast Louisiana. NASA sought to advance the use of remote sensing as an efficient and effective tool for identifying and classifying cultural resources located in the coastal wetlands where traditional surveying techniques are complicated by the difficult terrain.

As in previous similar surveying efforts, NASA utilized both LANDSAT and high-resolution hyperspectral and multi-spectral data from an airborne platform to develop predictive models of site location within the project area. Site files located at the State Archaeologists' Office in Baton Rouge were reviewed and those with relatively accurate location information were entered into a GIS. This enabled the location of sites on LANDSAT imagery. The study area was then flown with the ATLAS scanning radiometer at a spatial resolution of $4 \mathrm{~m}$ to refine site locations. The data was analyzed to extract spectral response curves for a variety of sites including shell middens and earthen mounds and the results were used as the basis for supervised classifications whose purpose was to identify high probability localities for undiscovered sites. Although this approach was not entirely new, it was augmented by the use of hyperspectral data which provided new information on the physical properties of land features, particularly vegetation and soils. One hundred and thirteen high potential localities were identified in the imagery of which more than $73 \%$ were validated through fieldwork.

\section{Space archaeology solicitation}

In 2008, for the first time in its history, NASA released a solicitation specifically addressing the use of remote sensing in archaeology. Seven projects were selected for funding including one by Douglas Comer, Cultural Site Research and Management, Inc., to develop software that will specifically identify archaeological site signatures from images acquired by means of NASA sensing platforms, in particular ASTER and Hyperion. Another by William Middleton of the Rochester Institute of Technology will analyze hyper- and multi-spectral satellite imagery from the Hyperion and ALI for the analysis of archaeological landscapes in Oaxaca. In another funded project, John Weishampel of the University of Central Florida will utilize hyperspatial satellite imagery and airborne LiDAR data to study ancient Maya land use at Caracol, Belize. The common theme among several of these NASA funded projects is hyperspectral remote sensing which is increasingly being investigated by archaeologists as the next potentially promising technology for research. A new NASA solicitation was released in 2009 and its resulting awards are pending.

\section{The future}

Remote sensing technology and image analysis are currently undergoing a profound shift in emphasis from broad classification to detection, identification and condition of specific materials, both organic and inorganic. In the last few years, remote sensing platforms have grown increasingly capable and sophisticated. Sensors currently in use, or nearing deployment, offer significantly finer spatial and spectral resolutions than were previously available. Paired with new techniques of image analysis, this technology may make the direct detection of archaeological sites a realistic goal (Jones and Giardino, 1997; Wiseman and El-Baz, 2007).

As of 2009 twenty-one NASA Earth Observing satellites are operating with 5 in development and 6 under study. One in particular, ASTER, is increasingly being utilized by archaeologists due to its high spatial resolution and broad spectral capabilities (Altaweel, 2005). ASTER is one of the five state-of-the-art instrument sensor systems onboard the Terra satellite launched in December 1999 as a cooperative effort between NASA and Japan's Ministry of Economy Trade and Industry (METI). The ASTER instrument provides improved remote sensing imaging capabilities compared with the older Landsat Thematic Mapper. ASTER's 14 multi-spectral bands monitor land temperature, land use, and vegetation patterns at a spatial resolution of $90-15 \mathrm{~m}$. ASTER is capable of producing stereoscopic images and detailed terrain height models. ASTER imagery has been collected already over several important archaeological sites including L'Anse aux Meadows in Newfoundland, where the remains of a Viking village were discovered in 1960; and the ruins of Machu Picchu, Mount Ararat, Teotihuacan, the Nasca Lines in Peru and Olduvai Gorge.

Even more exciting is the potential for adopting hyperspectral data in archaeological research. NASA's Hyperion sensor currently on an extended mission on the EO-1 platform provides relatively high resolution $(30 \mathrm{~m}$ ) hyperspectral images across 220 spectral bands (from 0.4 to $2.5 \mu \mathrm{m}$ ). Airborne hyperspectral sensors like NASA's Jet Propulsion Laboratory Airborne Visible InfraRed Imaging Spectrometer (AVIRIS) provide similar hyperspectral coverage at variable spatial resolutions (nominally at $17 \mathrm{~m} \mathrm{GSD}$ ). HYDICE 
(HYperspectral Digital Imagery Collection Experiment) collects data across 210 bands over the range similar to Hyperion and AVARIS (0.4-2.5 microns) but with greatly improved spatial resolution (1-4 $\mathrm{m}$ depending on the aircraft altitude and ground speed).

These new technologies offer archaeologists even more opportunities for research and analysis. One possible area where hyperspectral data can be very valuable is phytoarchaeology which is defined as the analysis of relationship between vegetation and archaeology (Brooks and Johannes, 1990: 9). Three specific areas of phytoarchaeology can greatly benefit from hypespectral imagery: 1 ) the identification of specific plant species that are associated with archaeological sites; 2) comparative plant physiology or the determination of plant stress or vigor; and 3 ) creation of a vegetation variability index.

For example, in Louisiana's coastal marsh landscapes, "upland" live oaks and associated plants like hackberries are often the first and most reliable evidence of a buried archaeological site (Brown, 1936). These trees are readily identifiable through their spectral response curves in remotely sensed images, especially those derived from hyperspectral data.

Secondly, the presence of plant stress (or vigor) indicators in remotely sensed data (generally in area of the "red edge" [0.68-0.75 microns]) may serve as a proxy for the presence of archaeological deposits. Hyperspectral data can be useful in identifying stress in vegetation, particularly when coupled with laboratory research. For example, in one experiment, the ratio of $R_{695}-R_{760}$ or $R_{800}$ was the most consistent stress indicator among several ratios tested (Carter, 1994; Giardino and Haley, 2006:51). Hyperspectral data can provide data in these narrow regions of the EMS.

Finally, hyperspectral data, in conjunction with algorithms for unmixing the spectral constituents of a given pixel, will be useful toward identifying sites through a third technical approach: development and use of a "vegetation variability index (VVI)". The premise underpinning the vegetation variability index is that vegetation on archaeological sites will exhibit higher species variability resulting from anthropogenic factors such as plant collecting, horticulture, waste production and disposal than the off-site communities (Traviglia, 2008; Dunn, 1983; Eleuterius and Otvos, 1979). Measuring variability in plant species over a given region becomes more feasible when using hyperspectral data and concomitant processing techniques.

\section{Conclusion}

NASA's mission seldom includes operational programs that sustain long-term observations of the Earth at scales and resolutions applicable to many archaeological research objectives. In fact, most of NASA's orbiting and airborne systems are one-of-a-kind instruments that provide proof of concept while gathering useful data on the Earth's systems. At this time, NASA does not plan to fly high spatial resolution sensors (finer than $15 \mathrm{~m} \mathrm{GSD}$ ) on orbiting platforms, thereby limiting the value of remotely sensed data for archaeology.

Still, whether through serendipitous opportunities, or through planned solicitation of archaeological projects, NASA will continue to provide archaeologists with a plethora of data and information to aid in their research. This is especially true for NASA's sub-orbital platforms carrying hyperspectral sensors that collect high spatial and spectral resolution data.

The technology developed by NASA and its contractors are refined and enhanced by commercial remote sensing companies. These organizations provide archaeologists with a wealth of observational and analytical opportunities. So too do several international sensors on both European and Indian platforms. Data archives such as NASA's Distributed Active Archives Centers (DAACs) and the USGS' EROS data center contain a nearly endless supply of remote sensing data and information that can benefit archaeological work. As with all well planned research, however, it is the responsibility of the investigator to construct testable hypotheses that can be addressed through the use of remotely sensed data.

In her report 1970 report, NASA summer intern Mary Scalera concluded (1970:26): "The space age has broadened the archaeologist's horizons. In fact, fantastic as it may sound, many have contemplated the expansion of archaeology to extraterrestrial discoveries. Archaeologists have been confronted with such questions as, 'What would you do if a discovery of past civilization was made on Mars?"' I have no doubt that should that event unfold, NASA will be ready to apply all its remote sensing tools and techniques to a new chapter of archaeological exploration.

\section{References}

Altaweel, M., 2005. The use of ASTER satellite imagery in archaeological contexts Archaeological Prospection 12 (3), 151-166.

Belew, L., Stuhlinger, E., 1973. Skylab: A Guidebook EP-107. U.S. Government Printing Office, Washington, D.C.

Bennett, J., Smith, L., Laustrup, M., 1986. The Red River Valley Archaeological Project. TIMS User Workshop JPL. California Institute of Technology.

Brooks, R., Johannes, D., 1990. Phytoarchaeology. Dioscorides Press, Portland, OR.

Brown, C., 1936. The Vegetation of the Indian Mounds, Middens, and Marshes in Plaquemines and St. Bernard Parishes. Department of Conservation-Louisiana Geological Survey 8. 423-440.

Carter, G., 1994. Ratios of leaf reflectances in narrow wavebands as indicators of plant stress. International Journal of Remote Sensing 15, 697-703.

Compton, D., Benson, C., 1983. Living and Working in Space: A History of Skylab. The NASA History Office Series, Scientific and Technical Information Branch, National Aeronautics and Space Administration, Washington DC.

Cook, J., Stringer, W., 1974. Feasibility Study for Locating Archaeological Village Sites by Satellite Remote Sensing Techniques. TLSP: Final Report, July 1972-January 1974. Alaska University Press, Fairbanks, Alaska.

Custer, J., Eveleigh, T., Klemas, V., Wells, I., 1986. Application of LANDSAT data and synoptic remote sensing to predictive models for prehistoric archaeological sites: an example from the Delaware coastal plain. American Antiquity 51, $572-588$

Dibble, L., 2006. Holocene Landscapes at Koobi Fora, Kenya: Application of Geographic Information Science to Archaeological Questions of Land use and Subsistence. PhD Dissertation, Rutgers University, May 2006.

Dunn, M., 1983. Coquille flora (Louisiana): an ethnobotanical reconstruction. Economic Botany 37, 349-359.

Ebert, J., Lyons, T., 1980. Prehistoric irrigation canals identified from Skylab III and Landsat imagery in Phoenix, Arizona. In: Lyons, T., Mathien, F. (Eds.), Cultura Resources Remote Sensing. Southwest Cultural Resources Center, National Park Service, Albuquerque, NM, pp. 209-228.

Eleuterius, L., Otvos Jr., E.G., 1979. Floristic and geologic aspects of Indian middens in salt marshes of Hancock County, Mississippi. SIDA, Contributions to Botany 8 , $102-112$.

Giardino, M., Haley, B., 2006. Airborne remote sensing and Geospatial analysis. In: Johnson, J. (Ed.), Remote Sensing in Archaeology: An Explicitly North American Perspective. University of Alabama Press, Tuscaloosa, AL, pp. 47-77.

Gibson, J., 1984. The Earthen Face of Civilization: Mapping and Testing at Poverty Point, 1983. Office of the State Archaeologist, Baton Rouge, Louisiana.

Gumerman, G., Lyons, T., 1971. Archaeological methodology and remote sensing. Science 172, 126-132.

Johnson, J., 2006. Remote Sensing in Archaeology. University of Alabama Press, Tuscaloosa, AL.

Johnson, J., Madry, S., Sever, T., 1988. Remote sensing and GIS analysis in large scale survey design in North Mississippi. Southeastern Archaeology 7 (2), 124-131.

Jones, P., Giardino, M., 1997. Recent Advances in Remote Sensing Technology Paper presented at the 54th Annual Meeting of the Southeastern Archaeological Conference, Birmingham, AL, November 5-8, 1997.

Junkin, B., Pearson, R., Seyfarth, B., Kalcic, M., Graham, M., 1981. Earth Resources Laboratory Applications Software (ELAS). Report No. 183. NASA, National Space Technology Laboratories, Earth Resources Laboratory, NSTL, MS.

Kahle, A., Abbott, E. (Eds.), 1986. The TIMS Data User's Workshop June 18 and 19 1985. NASA, Jet Propulsion Laboratory, California Institute of Technology, Pasadena, California.

Karsmizki, K., Spruce, J., Giardino, M., 2003a. Archaeological Remote Sensing: Searching for Fort Clatsop from Space Abstract in Proceedings for Society of Historical Archaeology, 2003 Conference, Providence, Rhode Island, January 14-19, 2003. 
Karsmizki, K., Spruce, J., Weymouth, J., Giardino, M., English, R., 2003b. Searching for Lewis and Clark's Iron Boat: Remote Sensing on the Ground and from Space Abstract in Proceedings for 2003 Society of American Archaeology Conference, Milwaukee, Wisconsin, April 9-14, 2003.

Karsmizki, K., Spruce, J., Giardino, M., 2004. Use of Remote Sensing and GIS in Search for Lewis and Clark's Rock Fort Camp Site of the Dalles, Oregon. Presentation Given at 2004 ESRI Conference, 9-13 Aug. 2004, San Diego, CA, United States.

Kruchman, L., 1976. Remote sensing and archeology: a preliminary bibliography. RSEMS, Newsletter of the Remote Sensing Committee of the Association of American Geographers, Volume. 3, No. 2.

Limp, F., 1989. The Use of Multi spectral Digital Imagery in Archaeological Investigations. Arkansas Archaeological Survey Research Series no. 34.

Lyons, T., Avery, T., 1977. Remote Sensing: a Handbook for Archeologists and Cultural Resource Managers. National Park Service, U.S. Government Printing Office, Washington, DC.

Lyons, T., Ebert, J. (Eds.), 1978. Remote Sensing and Non-Destructive Archeology. Cultural Resources Management Division, National Park Service, Washington, D.C.

Reports of the Chaco Center, No. 2. In: Lyons, T., Hitchcock, R. (Eds.), Aerial Remote Sensing Techniques in Archeology. National Park Service and University of New Mexico, Albuquerque, NM.

Lyons, T., Mathien, F. (Eds.), 1980. Cultural Resources Remote Sensing. Cultura Resources Management Division, National Park Service, Washington D.C.

Madry, S., 1983. Remote sensing in archaeology. Archaeology, 18-19. May-June, 1983.

MASCA Newsletter, November, 1969. "Balloon and Airfoil photography", Applied Science Center for Archaeology, University of Pennsylvania, vol. 5, No. 2, p. 2 and 3

Mid-America Remote Sensing Center, 1983 Determination of the Utility of Remote Sensing Data for Land Use/Cover Analyses in the Lower Appalachia RegionAssessing the Utility of Remote Sensing Data for Archaeological Site Reconnaissance. NASA Contract NAS13-200 Murray State University.

McKee, B., Sever, T., 1994. Remote sensing in the arenal region. In: Sheets, P. McKee, B. (Eds.), Archaeology, Volcanism and Remote Sensing in the Arenal Region, Costa Rica. University of Texas Press, Austin, TX., pp. 135-141.

Miller, W.F., 1974. Applications of Remote Sensing in Archeological Site Identification. Institute of Environmental Studies, Mississippi State University.
NASA/SSC, 2003. The NASA Scientific Data Purchase Final Report. National Aeronautics and Space Administration, John C. Stennis Space Center, Mississippi. September 2003 (Contract Number 13-650).

Parcak, S., 2009. Satellite Remote Sensing for Archaeology. Routledge Press, New York, NY.

Rickman, D., Kalcic, M., 1982. Noise Removal by Principal Component Analysis. Report No. 203. NASA National Space Technology Laboratories, Earth Resources Laboratory, NSTL, MS.

Scalera, M., 1970. Aerial Archaeology in the Space Age. NASA Historical Division, Office of Policy. August 1970 NASA-TM-X-68502.

Schaber, G., Gumerman, G., 1969. Infrared scanning images: archaeological application. Science 164 (880), 712-713.

Sever, T., 1983. Feasibility Study to Determine the Utility of Advanced Remote Sensing Technology in Archeological Investigations. Report No. 227 December 1983 (NASA-TM-88650). NSTL, ERL.

Sever, T., Wiseman, T., 1985. Conference on Remote Sensing: Potential for the Future. January 1985. NASA Earth Resources Laboratory, NSTL, MS

Sever, T., Wagner, D., 1991. Analysis of prehistoric roadways in Chaco Canyon using remotely sensed digital data. In: Trombold, C. (Ed.), Ancient Road Networks and Settlement Hierarchies in the New World. University Press, Cambridge, pp. 42-52.

Short, N., 1982. The Landsat Tutorial Handbook: Basics of Satellite Remote Sensing. NASA Reference Publication 1078. Scientific and Technical Branch, National Aeronautics and Space Administration, Washington D.C.

Traviglia, A., 2008. A view of Greater Angkor: a multi-scalar approach for investigating the Khmer forests. In: Lasaponara, R., Masini, N. (Eds.), Proceedings of the 1st International EARSeL Workshop: Advances in Remote Sensing for Archaeology and Cultural Heritage Management, Rome, September 30-October 4, 2008. Aracne Press, Rome, Italy, pp. 23-26.

Wells, I., Custer, J., Klemas, V., 1981. Locating prehistoric archaeological sites using Landsat International Symposium on remote sensing of Environment, 15th, Ann Arbor, MI, May 11-15, 1981. In: Proceedings, vol. 2. Environmental Research Institute of Michigan, 1981, Ann Arbor, MI, pp. 771-780.

Wiseman, J., 1984. Archaeology in the Space Age, Context 4: I-2, pp. I-3. Boston University.

Wiseman, J., El-Baz, F., 2007. Remote Sensing in Archaeology. Springer Press, New York, NY. 